\title{
PENDIDIKAN AGAMA KRISTEN SEBAGAI STRATEGI MENUMBUHKAN IMAN ANAK DIDIK MELALUI PERAN GURU YANG PARIPURNA DIMASA PANDEMI COVID 19
}

\author{
Salomo Panjaitan, BD. Nainggolan, Stimson Hutagalung, Rolyana Ferinia \\ Universitas Advent Indonesia \\ pdtspanjaitan7day@gmail.com
}

\begin{abstract}
The purpose of this study was to conduct a study on the role of Christian Religious Education as a strategy in growing the faith of students through the complete role of teachers during the COVID-19 Pandemic. The research method used was a qualitative research method. The analysis process used by the author is to use the Bible as the main source and also some actual and reliable literature sources related to the title in this article so as to produce a study that can be accounted for by using several stages of research, including description or orientation stage, stage reduction, and selection stage. The results of the research include the complete role of teachers during the COVID-19 pandemic, including: Teachers as Educators. Teachers must have personal quality standards that include responsibility, authority, independence and discipline. PAK religious teachers who understand the Science of Technology, the ability to follow the development of Science Technology is a very important thing owned by a PAK religion teacher, so that students feel happy to follow the subject. Religious Teachers and Parents of Students. As teachers who care about their students, religious teachers will also open communication with their students' parents, so that religious teachers know their situation and will facilitate communication and education to their students.
\end{abstract}

Keywords: Teacher's Role; Faith Growth; Christian Religious Education

\begin{abstract}
Abstrak
Tujuan dari penelitian ini adalah untuk mengkaji mengenai peranan Pendidikan Agama Kristen sebagai strategi untuk menumbuhkan iman anak didik melalui peran guru yang paripurna di masa Pandemi COVID 19. Metode penelitian yang dipakai yaitu metode penelitian kualitatif. Proses analisa yang di gunakan penulis yaitu menggunakan Alkitab selaku sumber utama serta juga beberapa sumber literatur yang aktual dan bisa di percaya yang berhubungan dengan judul dalam artikel ini sehingga menghasilkan suatu kajian yang dapat dipertanggungjawabkan dengan menggunakan beberapa tahapan penelitian, antara lain deskripsi maupun tahap orientasi, tahap reduksi, serta tahap seleksi Hasil penelitian antara lain peran guru yang paripurna di masa Pandemi COVID 19 antara lain: Guru Sebagai Pendidik. Guru wajib mempunyai standar kualitas pribadi yang meliputi tanggung jawab wibawa, mandiri serta disiplin. Guru agama PAK yang memahami Ilmu Teknologi, Kemampuan mengikuti perkembangan Ilmu Teknologi merupakan hal yang pokok dipunyai seorang guru agama PAK, sehingga anak didik merasa senang mengikuti mata pelajarannya. Guru agama dan orangtua anak didik-sebagai guru yang peduli kepada anak didiknya, guru agama akan membuka komunikasi juga dengan orangtua anak didiknya, agar guru agama mengetahui keadaan mereka dan akan mempermudah komunikasi dan pendidikan kepada anak didiknya.
\end{abstract}


Kata Kunci: Peran Guru; Pertumbuhan Iman; Pendidikan Agama Kristen

\section{PENDAHULUAN}

Dalam pelayanan kepada anak-anak, Gereja harus mengetahui baik iman yang ingin dikomunikasikan maupun anak yang dilayaninya. Pemahaman dasar tentang karakteristik dan kebutuhan anak sangat penting untuk membantu mereka secara efektif dalam perkembangan mereka. Perkembangan manusia pada masa kanak-kanak merupakan periode formatif yang mendalam ketika perspektif dibentuk baik secara positif atau negatif berupa pandangan tentang kebutuhan yang bertanggung jawab untuk mengubah dunia masa depan ${ }^{1}$.

Pandangan tersebut merupakan panggilan seperti yang ditunjukkan dalam Maleakhi 4:6 untuk mengarahkan hati kepada anak-anak mereka dalam berbagai ukuran, bentuk, dan perilaku. Dalam banyak hal, anak-anak adalah sama namun berbeda karena mereka adalah individu dengan haknya sendiri, maka mereka bukan orang dewasa dan kita tidak boleh mengharapkan perilaku orang dewasa dari mereka. Meskipun otoritas yang berbeda menekankan jumlah tahap perkembangan yang berbeda, perkembangan anak mengacu pada kemampuan anak untuk belajar dan menguasai keterampilan yang disebut tonggak seiring bertambahnya usia ${ }^{2}$

Tahapan perkembangan anak dimulai sejak lahir, karena perkembangan dipengaruhi oleh faktor keturunan dan lingkungan sehingga seringkali akan sangat berbeda dengan anak lainnya. Masa kanak-kanak adalah periode yang berbeda dalam kehidupan seperti masa remaja atau dewasa. Masa kanak-kanak berlangsung sejak lahir sampai usia sebelas tahun. Menurut Paris, Ricardo, \& Rymond membaginya menjadi lima tahapan sebagai berikut: ${ }^{3}$

a. Perkembangan Prenatal (konsepsi sampai lahir)

Konsepsi dimulai saat semua struktur tubuh sedang terbentuk dan kesehatan ibu menjadi perhatian utama dengan memberikan perhatian utama pada nutrisi, teratogen (atau faktor lingkungan yang dapat menyebabkan cacat lahir), serta persalinan dan kelahiran

b. Bayi dan Balita (lahir sampai dua tahun)

Dua tahun kehidupan adalah masa pertumbuhan dan perubahan yang dramatis. Bayi yang baru lahir, dengan indera pendengaran yang tajam tetapi penglihatan yang sangat buruk berubah menjadi balita yang bisa berjalan dan berbicara dalam waktu yang relatif singkat.

c. Anak Usia Dini (3 sampai 5 tahun)

Anak usia dini juga dinamakan juga menjadi tahun-tahun prasekolah dan terdiri dari tahun-tahun yang mengikuti masa balita. Sebagai anak berumur tiga sampai lima tahun, anak sibuk belajar bahasa, memperoleh rasa diri serta kemandirian yang makin tinggi, serta mulai belajar cara kerja dunia fisik. Pengetahuan ini tidak datang dengan cepat, bagaimanapun, dan anak-anak prasekolah mungkin

\footnotetext{
${ }^{1}$ Alice W. Mambo, "Understanding Developmental Characteristics of a Child in Christian Faith among Sunday-School Children in Kenya," IRA International Journal of Education and Multidisciplinary Studies 14, no. 3 (2019): 54.

${ }^{2}$ Eugene Kreider, "Faith Development in Educational Ministry with Children," World XV, no. 1 (1995).

3 Jennifer Paris, Antoinette Ricardo, and Dawn Rymond, Child Growth and Development, The American Catholic Sociological Review, vol. 11 (California: California Community Colleges, Chancellor's Office., 2019).
} 
awalnya memiliki konsepsi yang menarik tentang ukuran, waktu, ruang dan jarak seperti rasa takut

d. Anak Usia 6-11 tahun

Usia enam sampai sebelas tahun terdiri dari masa kanak-kanak tengah dan banyak dari apa yang dialami anak-anak di umur tersebut terhubung dengan partisipasi mereka di awal sekolah. Dunia menjadi salah satu tempat belajar dan menguji keterampilan akademik baru dan dengan menilai kemampuan dan pencapaian seseorang dengan menyusun perbandingan diantara diri sendiri serta orang lain. Tingkat pertumbuhan melambat dan anak-anak dapat memperbaiki keterampilan motorik mereka pada saat ini dalam kehidupan serta anak-anak mulai belajar tentang hubungan sosial di luar keluarga melalui interaksi dengan teman dan sesama siswa.

e. Masa remaja (12 tahun sampai dewasa)

Masa remaja merupakan tahap perubahan fisik yang dramatis yang ditandai dengan percepatan perkembangan fisik dengan keseluruhan serta pematangan seksual, yang diketahui menjadi pubertas. Hal tersebut adalah masa perubahan kognitif saat remaja mulai memikirkan peluang-peluang baru serta mempertimbangkan konsep-konsep abstrak misalnya cinta, ketakutan, serta kebebasan.

Pertumbuhan Iman merupakan cara hidup seseorang atau komunitas dalam hubungannya dengan lingkungan akhir ${ }^{4}$. Dalam pengertian ini, iman adalah tri-polar yang dinyatakan dengan istilah Kerajaan Allah dan merupakan pusat nilai dan kekuasaan. Pemahaman akan iman tidak dapat dipisahkan dari iman sebagai pengetahuan aktif dan keberadaan di mana membuat hubungan dari pusat nilai dan kekuatan yang meliputi mencintai, peduli, menghargai, dan juga kekaguman, ketakutan, dan ketakutan. Menurut Van Niekerk dan Gert, pentingnya pertumbuhan iman pada anak - anak antara lain $:^{5}$

a. Iman anak-anak bisa hancur.

Ingatkah ketika murid-murid Yesus menegur orang-orang yang membawa anakanak kepada-Nya untuk diberkati? Ketika Yesus melihat tindakan mereka, dia tidak senang. "Biarkan anak-anak datang kepadaku, dan jangan melarang mereka, karena mereka adalah pemilik kerajaan surga." (Matius 19:14). Anakanak memiliki hak serta keinginan untuk masuk ke hadirat Yesus. Dalam iman mereka yang polos dan kekanak-kanakan, anak-anak sering membagikan permintaan doa tentang hewan peliharaan, mainan, kegiatan mendatang, pahlawan televisi, dan anggota keluarga mereka sehingga mendorong mereka untuk percaya dan percaya kepada Tuhan. Permintaan doa mungkin tampak mustahil bagi orang dewasa tetapi Tuhan mendengarkan dan menanggapi anakanak-Nya.

\footnotetext{
${ }^{4}$ Mambo, "Understanding Developmental Characteristics of a Child in Christian Faith among SundaySchool Children in Kenya."

${ }_{5}^{5}$ Marsulize Van Niekerk and Gert Breed, "The Role of Parents in the Development of Faith from Birth to Seven Years of Age," HTS Teologiese Studies / Theological Studies 74, no. 2 (2018): 1-11.
} 
b. Iman anak-anak tidak memiliki batas ${ }^{6}$.

Setiap kali kita mengajarkan Firman kepada anak-anak dan mereka menerimanya, iman mereka tumbuh dalam Sekolah Minggu, pelajaran Alkitab, dan pengalaman interaktif yang memberikan anak-anak kesempatan untuk menumbuhkan iman mereka. Dengan pengalaman positif yang konsisten, anakanak dapat melatih iman mereka dan menghasilkan pertumbuhan lebih lanjut

c. Iman anak-anak harus berdasarkan Alkitab ${ }^{7}$.

Pengetahuan tentang Firman Tuhan adalah dasar iman anak-anak yang sehat berdasarkan dasar kitab suci yang kuat Media seharusnya tidak hanya digunakan untuk membuat anak-anak tetap terlibat. Alat berbasis media apa pun yang digunakan perlu secara langsung mendukung perkembangan iman anak-anak dengan memiliki hubungan yang jelas dengan apa yang mereka pelajari di kelas.

d. Perkembangan iman anak-anak berdampak pada takdir kekal mereka.

Dampak dari membangun iman yang kuat sekarang dapat menghasilkan hubungan yang sehat dengan Yesus dan gereja di masa depan. Perkembangan moral anak-anak selesai pada usia sembilan tahun, Perkembangan moral dan nilai anak-anak membuktikan bahwa fondasi nilai dan moral sepanjang hayat terbentuk selama tahun-tahun awal anak-anak.

Dari permulaan tahun 2020, dunia internasional menghadapi sederetan perubahan paradigma yang luar biasa dalam menghadapi pandemi Covid - 19, Dunia mulai terbiasa agar bekerja dari rumah, bersekolah dari rumah, serta melakukan ibadah dari rumah. Perubahan yang sangat drastis ini menunjukkan bahwa kehidupan di dunia telah berubah sehingga kita butuh menyiapkan diri dalam zaman lain yang tidak sama yang memerlukan paradigma baru dan kompetensi yang berbeda. Kementerian Agama Republik Indonesia juga memberikan kebijakan untuk mendorong komunitas gereja dalam melakukan peribadatan dan Sekolah Minggu secara daring ${ }^{8}$.

Namun dalam pelaksanannya, banyak terjadi kendala dan hambatan penyelenggaraan kegiatan peribadatan dan Sekolah Minggu secara daring. Menurut penelitian yang dilakukan Karnawati dan Mardiharto pada tahun 2020 menyatakan bahwa banyak kendala yang ditemukan dalam peribadatan secara daring, antara lain siswa maupun Guru Sekolah Minggu belum mengetahui penggunaan sarana teknologi dengan baik, kurangnya kuota dalam peribadatan secara daring sehngga peran dan fungsi pelayanan anak-anak selama pandemi Covid-19 sangat mengecewakan karena tidak dilaksanakan pembelajaran yang berorientasi pada anak-anak ${ }^{9}$

Permasalahan berikutnya menurut Sogen, Firmanto, dan Aluwesia pada tahun 2021 adalah Para pendamping belum menemukan metode yang tepat untuk menumbuhkan iman para remaja Katolik. Metode yang kurang tepat tentu akan membuat para remaja Katolik semakin bingung dan bosan. Metode yang tidak sesuai akan membuat suasana pembinaan iman secara daring semakin membosankan.

\footnotetext{
6 Tony P. Lane, "7 Essentials for Growing Kids' Faith," Childrensministry, last modified 2021, https://childrensministry.com/faith-to-grow-on/.

${ }^{7}$ Ibid.

${ }^{8}$ Kementerian Agama Republik Indonesia, "Ketentuan Kegiatan Di Rumah Ibadah Pada PPKM 10 - 16 Agustus 2021," Kemenag RI, last modified 2021, https://kemenag.go.id/read/ketentuan-kegiatan-dirumah-ibadah-pada-ppkm-10-16-agustus-2021-gmn9k.

${ }^{9}$ Karnawati Karnawati and Mardiharto Mardiharto, "Sekolah Minggu Masa Pandemi Covid 19: Kendala, Solusi, Proyeksi," Didache: Journal of Christian Education 1, no. 1 (2020): 13.
} 
Kebosanan akibat metode yang kurang tepat tentu akan membuat remaja hilang arah serta pertumbuhan dan perkembangan iman remaja katolik terhambat ${ }^{10}$.

Berdasarkan permasalahan yang sudah dijabarkan diatas, maka perlunya peranan guru melalui pengajaran Pendidikan Agama Kristen pada anak - anak. Dalam pandangannya, Telaumbanua Arozatulo menyatakan tanggung jawab yang ditanggung dari tiap-tiap guru Pendidikan Agama Kristen yang sudah disiapkan yang terdiri dari: ${ }^{11}$

a. Guru Memberikan Dirinya Kepada Murid

Guru Pendidikan Agama Kristen adalah protagonis keberhasilan pendidikan di sekolah. Ini sama dengan ayat, "Gembalakanlah kawanan domba Allah, bukan karena paksaan, tetapi dengan sukarela, menurut kehendak Allah, bukan untuk keuntungan, tetapi dengan rakus" (1 Petrus 5:2)."

b. Guru Menjadi Teladan Kepada Murid

"Jangan biarkan siapa pun berpikir Anda lebih rendah hanya karena Anda masih muda. Jadilah teladan bagi orang-orang yang beriman dalam perkataan, perbuatan, cinta, kesetiaan, dan kesucian. (1 Timotius 4:12)"

c. Guru Membawa Murid Kepada Perubahan Hidup

Guru pendidikan agama Kristen berperan sebagai guru yang mengajarkan visi dan misi kedatangan Yesus ke dunia, seperti menemukan dan menyelamatkan domba yang hilang dan berdosa.

Apakah upaya ini akan berhasil? Tentu hasilnya akan maksimal bilamana seorang guru agama itu terlebih dahulu menjadi teladan pola hidup yang beriman, dan membagikan pengalamannya sendiri saat berjalan dengan imannya bersama Tuhan. Sekarang ini banyak orang hidupnya susah karena Pandemi Covid 19, sehingga pada saat seorang guru agama menceritakan pertolongan Tuhan dalam kesusahan hidupnya, maka anak didik akan merasa termotivasi untuk mengalami sendiri kehidupan beriman. Selain itu, sangatlah penting seorang guru agama mengetahui Ilmu Teknologi agar dapat menolong anak didik mengguakan media sosial untuk mengikuti Pelajaran Agama Kristen dalam pertumbuhan iman mereka. Priscillia Diane, Joy Joseph dan Fredik Melkias Boiliu mengatakan penyalahgunaan teknologi di era sekarang terhadap anak bisa berpengaruh jelek dalam kehidupan mereka. Pendidikan agama Kristen memiliki peran dalam memberi pemahaman serta kesadaran terhadap anak untuk pemakaian teknologi serta bahaya pemakaian teknologi. Peran tersebut dijalankan di lingkungan keluarga, sekolah dan gereja yang bertujuan dalam mengantisipasi pemakai teknologi terhadap anak di zaman sekarang. ${ }^{12}$ Tujuan penelitian ini adalah melakukan kajian mengenai peranan Pendidikan Agama Kristen sebagai strategi dalam menumbuhkan iman anak didik melalui peran guru yang paripurna di masa Pandemi COVID 19

\section{METODE}

Metode penelitian yang dipakai adalah metode kualitatif. Penelitian ini menekankan kepada kajian teori. Pendekatan teori kualitatif merupakan pendekatan

\footnotetext{
${ }^{10}$ Dimas Sandy et al., "Perkembangan Iman Rasul Cilik Pada Masa Pandemi Covid-19 Paroki Santa Perawan Maria Dari Gunung Karmel Ijen Malang” (n.d.): 11-24.

11 Arozatulo Telaumbanua, "Peranan Guru Pendidikan Agama Kristen Dalam Membentuk Karakter Siswa," FIDEI: Jurnal Teologi Sistematika dan Praktika 1, no. 2 (2018): 219-231.

12 Priscillia Diane, Joy Joseph, and Fredik Melkias Boiliu, "EDUKATIF: JURNAL ILMU PENDIDIKAN Peran Pendidikan Agama Kristen Dalam Penggunaan Teknologi Pada Anak" 3, no. 4 (2021): 2037-2045.
} 
dengan menggunakan landasan teori digunakan menjadi panduan supaya fokus penelitian berdasarkan fakta dilapangan ${ }^{13}$ Kajian literatur yang berkaitan dengan judul menjadi fokus pembahasan, landasan teori berguna juga dalam memberi gambaran umum mengenai latar belakang penelitian serta menjadi bahan pembahasan hasil penelitian.

\section{HASIL DAN PEMBAHASAN}

Hasil dan pembahasan karya ilmiah ini diuraikan sebagai berikut:

\section{A. Peran penting Guru Agama PAK di Sekolah Dalam Membetuk Karakter Beriman Bagi Anak Didik}

Guru agama perlu menyadari bahwa keberadaannya di sekolah sangatlah penting, karena menyangkut iman, dan karakter anak didik sebagai calon pemimpin di masa yag akan datang. Arozatulo Telaumbanua mengatakan Guru adalah orang yang mendapat kepercayaan Tuhan untuk menjalankan pendidikan serta pengajaran berdasarkan karunia yang sudah diberikan padanya. Elisabeth Sitepu mengatakan bahwa PAK adalah pendidikan yang berporos terhadap pribadi Tuhan Yesus Kristus dan Alkitab (Firman Tuhan) menjadi landasan peranan PAK yang begitu pokok sekali di sekolah dalam meningkatkan kualitas spiritualisme siswa. Dengan harapan apabila hasil belajar siswa baik/bagus maka siswa juga berperilaku dan bermoral baik di sekolah maupun dimanapun siswa tersebut berada. ${ }^{14}$

\section{Guru Sebagai Pendidik,}

Guru wajib mempunyai pedoman kualitas pribadi yang meliputi tanggung jawab, wibawa, mandiri serta disiplin. Guru PAK adalah pembina dan pendidik, sesuai pengetahuan serta pengalamannya wajib bisa membina serta memiliki tanggung jawab dari perjalanan serta perkembangan karakter di dalam Yesus Kristus. Stimson Hutagalung mengatakan bahwa "Pendidikan karakter dan pendidikan moral adalah pembelaan diri terhadap korupsi moral yang disebabkan oleh korupsi moral yang mengarah pada kehancuran bangsa." 15 Itulah sebabnya, guru agama PAK perlu memberikan perhatian besar kepada anak didiknya demi kepentingan bangsa. Selanjutnya beliau mengatakan Membangun karakter dengan pengontrolan emosi, peningkatan kerohanian, serta pengelolaan kepribadian adalah perilaku yang butuh dilaksanakan sekarang ini, sebab pembangunan karakter tersebut tidak terbangun dengan otomatis serta memerlukan pengembangan dari waktu ke waktu melewati berbagai tahapan. ${ }^{16}$ Stimson Hutagalung juga mengatakan "ada pelemahan moral di banyak tempat ketika sekolah-sekolah Kristen mempersiapkan anak-anak mereka untuk era digital. Kemerosotan moral kaum muda semakin terasa. Ini adalah masalah besar, terutama bagi anak muda saat ini. Degradasi kualitas moral terjadi dalam berbagai cara, termasuk ucapan, pakaian, dan perilaku. Perkelahian pelajar, pemerasan, kekerasan, intimidasi, dominasi orang tua atas anak di bawah umur, kenakalan remaja, dan kecanduan narkoba ada di mana-mana."17

\footnotetext{
${ }^{13}$ Sugiyono, "Metode Penelitian Kuantitatif Kualitataif Dan R\&D” (Bandung: Alfabeta, 2016), 80.

${ }^{14}$ Elisabet Sitepu, Thomas P Tarigan, and Desy N Simatupang, "( $(38,18<113,14)$ Dan Data Normalitas Hasil Belajar PAK Berdistribusi Normal Dengan Hasil Perhitungan Diperoleh X” 1 (2019): 23-27.

${ }^{15}$ Stimson Hutagalung and Rolyana Ferinia, "Pengaruh Dekadensi Moral Terhadap Pendidikan Karakter Dan Bimbingan Konseling Pada Siswa Kristen,” Kurios 7, no. 1 (2021): 178.

${ }^{16}$ Ibid.

17 Ibid.
} 


\section{B. Guru Agama PAK Yang Memahami Ilmu Teknologi}

Sekarang ini dunia sedang mengalami pandemi covid 19, dan mengharuskan manusia berkomunikasi dengan media online atau internet. Kemampuan mengikuti perkembangan Ilmu Teknologi merupakan hal yang begitu utama dipunyai seorang guru agama PAK, sehingga anak didik merasa senang mengikuti mata pelajarannya. Arozatulo Telaumbanua mengatakan Perkembangan IPTEK maupun perubahan zaman, bukan sebagai alasan untuk para pengajar agar tidak menyampaikan Pendidikan Agama Kristen serta menjalankan perannya menjadi guru yang mendapatkan kepercayaan dari Allah untuk mengajar serta membangun kepribadian siswa. ${ }^{18}$ Pengetahuan Ilmu Teknologi untuk menghubungkan minat anak didik melului media sosial yang mereka minati akan menolong mereka menyenangi PAK, dan menolong mereka menemukan kebenaran Firman Tuhan yang perlu mereka lakukan.

Strategi guru agama PAK

Seorang guru agama harus mempersiapkan strategi bagus untuk membuat anak didiknya selalu mendapatkan hal-hal yang baru. Ester Putri Setiyowati mengatakan diharap bisa memiliki strategi pokok yang harus dimengerti guru untuk melaksanakan pembelajaran yang efektif, yaitu berhubungan terhadap wawasan serta keterampilan profesional dan komitmen, motivasi, serta kesabaran. Guru yang baik memiliki klasifikasi dalam Pemahaman Materi Kurikulum, Strategi Mengajar, Keterampilan Penetapan Tujuan dan Perencanaan Pembelajaran, Keterampilan Pengelolaan Kelas, Keterampilan Inspirasional, Keterampilan Motivasi, Keterampilan Komunikasi, Keterampilan Memahami Keberagaman Siswa, dan Keterampilan Pemanfaatan Keterampilan.. ${ }^{19}$ Dengan begitu, guru akan memiliki kemampuan untuk untuk menumbuhkan semangat dan kebahagiaan dari belajar PAK di sekolah. Selanjutnya beliau mengatakan Sarana serta sumber belajar pun diperlukan dalam menunjang aktivitas belajar, misalnya buku sumber, sumber belajar, alat peraga, media, maupun peralatan khusus yang dipakau pada kegiatan pembelajaran. ${ }^{20}$ Tjandra mengatakan Topik PAK dapat dikemas sedemikian rupa ke dalam berbagai model pembelajaran abad 21. Strategi dalam Pembelajaran Abad 21 dapat membantu Anda menciptakan pembelajaran yang kreatif, bersemangat, dan bebas stres. ${ }^{21}$ sehingga, anak didik bukan hanya memiliki ketrampilan dan pengetahuan Ilmu Teknologi, tetapi yang istimewa adalah mereka mengalami pertumbuhan iman dan karakter seperti Yesus Kristus.

Seorang guru agama haruslah menyadari bahwa apa yang ditabur tersebut yang hendak dituai yang tertulis dalam Galatia 6:7 "Apa yang ditabur orang, itu juga yang akan dituainya." Jadi, bilamana seorang guru mengajar dan mendidik anak didiknya dengan banyak cara kebaikan, maka akan menghasilkan anak didik yang perpotensi dan berkarakter baik.

\section{Guru Agama dan Orangtua Anak didik}

Sebagai guru yang peduli kepada anak didiknya, guru agama akan membuka komunikasi juga dengan orangtua anak didiknya, agar guru agama mengetahui keadaan

\footnotetext{
${ }^{18}$ Telaumbanua, "Peranan Guru Pendidikan Agama Kristen Dalam Membentuk Karakter Siswa."

${ }^{19}$ Ester Putri Setiyowati and Yonatan Alex Arifianto, "Hubungan Kompetensi Pedagogik Guru Dan Prestasi Belajar Siswa Pada Mata Pelajaran Pendidikan Agama Kristen,” SIKIP: Jurnal Pendidikan Agama Kristen 1, no. 2 (2020): 78-95.

${ }^{20}$ Telaumbanua, "Peranan Guru Pendidikan Agama Kristen Dalam Membentuk Karakter Siswa."

${ }^{21}$ Daniel S. Tjandra, "Impelementasi Pembelajaran Pendidikan Agama Kristen Di Abad 21," SIKIP: Jurnal Pendidikan Agama Kristen 1, no. 1 (2020): 1-10.
} 
mereka dan akan mempermudah komunikasi dan pendidikan kepada anak didiknya. Stimson Hutagalung mengatakan: "Harus ada kerjasama segitiga sama sisi antara sekolah, orang tua dan anak. Segitiga sama sisi melambangkan hubungan yang sangat kuat antara sekolah, orang tua dan anak untuk memotivasi, mendedikasikan dan mencegah moral siswa. Mendorong orang tua untuk berpartisipasi di sekolah adalah cara yang efektif.",22 Kerjasama yang baik diantara guru serta orangtua akan menjadikan pendidikan itu lebih akurat tersalur kepada anak didik di sekolah.

Mengapa guru perlu berkomunikasi untuk berkerjasama membimbing anak didik? Jawabannya adalah karena orangtualah yang sebenarnya guru pertama anak didik tersebut, merekalah yang mendidik anak-anaknya sejak bayi hingga mengecap dunia pendidikan di sekolah, dan pulang sekolah anak didik kembali ke rumah orangtuanya untuk berada pada pengawasan orangtua mereka. Talizaro menuliskan bahwa sehingga selaku orang tua wajib memberi pendidikan pada anaknya. Atau, jika orang tua adalah pengasuh utama, Talisaro dapat mengatakan bahwa tanggung jawab orang tua dalam pendidikan anak mereka meliputi:

Pertama, "Orang tua menciptakan komunikasi yang sangat efektif untuk anakanak mereka. Di zaman modern ini, banyak orang tua yang tidak dapat berkomunikasi dengan anak-anak mereka. Dengan munculnya ponsel, orang tua jarang berkomunikasi dengan anak-anak mereka. Orang tua sangat sibuk menggunakan ponselnya atau menjawab panggilan orang lain daripada mengajak anaknya mengobrol. Padahal, menciptakan komunikasi dengan anak sangat penting karena komunikasi dapat mempererat hubungan antara orang tua dan anak."

Kedua, Dengarkan dan perhatikan anak-anak. Penting tidak hanya untuk berkomunikasi secara efektif dengan anak-anak, tetapi juga untuk mendengarkan dan memperhatikan. Anak-anak biasanya membutuhkan telinga yang mau mendengar dan wajah yang selalu memperhatikan. Namun ironisnya, masih ada orang tua yang tidak memberikan kesempatan kepada anaknya untuk berbicara, sehingga anak meremehkan dirinya sendiri, dan anak tidak mau mendengarkan orang tuanya dan berpaling. ${ }^{24}$

Ketiga, Orang tua mendorong atau memotivasi anak-anak mereka. Orang tua memiliki tanggung jawab untuk memotivasi anak-anaknya secara positif dalam beberapa cara sehingga mereka merasa nyaman dengan orang tua yang baik yang selalu menerima kelebihan dan kekurangan mereka. Orang tua juga perlu memperhatikan kehidupan anaknya setiap hari. Orang tua harus sangat serius dalam mendidik dan membimbing anak-anaknya, karena kebanyakan anak-anak suka bermain-main karena kurangnya perhatian orang tua bahkan di zaman modern ini. ${ }^{25}$

Keempat, Orang tua memberikan waktu luang kepada anak-anaknya. Salah satu masalah paling umum di rumah akhir-akhir ini adalah sulitnya menghabiskan waktu khusus dengan anak-anak, dan banyak orang tua yang sibuk dengan pekerjaan dan halhal lain. Waktu bersama keluarga merupakan kebahagiaan tersendiri bagi anak-anak. Kebahagiaan tidak selalu datang dengan kekayaan. Tapi persahabatan dengan keluarga

\footnotetext{
${ }^{22}$ Hutagalung and Ferinia, "Pengaruh Dekadensi Moral Terhadap Pendidikan Karakter Dan Bimbingan Konseling Pada Siswa Kristen."

${ }^{23}$ Talizaro Tafonao, "Peran Pengajaran Pendidikan Agama Kristen Dalam Keluarga Sangat Penting Untuk Diajarkan Kepada Anak-Anak, Baik Dalam Keluarga, Sekolah, Di Tempat Ibadah Dan Masyarakat, Agar Kelak Anak-Anak Dapat Menghadapi Setiap Problem Secara Kognitif, Afektif Dan Psik," Edudikara: Jurnal Pendidikan dan Pembelajaran 3, no. 2 (2018): 125.

24 Ibid.

25 Ibid.
} 
sangat penting. Jika orang tua kurang memperhatikannya, anak akan menjadi korban pengaruh dunia modern dan kompleks. ${ }^{26}$

Kelima, Orang tua harus mampu menciptakan lingkungan keluarga yang mendukung bagi anak-anaknya. Lingkungan rumah merupakan salah satu faktor yang mempengaruhi tumbuh kembang anak. Orang tua harus mampu menciptakan suasana keluarga yang penuh kasih sayang. Artinya, keluarga harus menjaga keharmonisan satu sama lain. Ketika anak-anak tumbuh dalam rumah tangga yang bahagia tanpa kekerasan, mereka akan bahagia dan memiliki semangat yang baik. Namun, ketika seorang anak tumbuh dan tumbuh dalam keluarga dengan banyak perilaku kekerasan, anak tersebut menjadi pemberontak. ${ }^{27}$

Keenam, Orang tua menjadi sahabat anak. Orang tua harus hadir saat dibutuhkan dan bisa menjadi teman. Cara mendidik anak yang baik dan tepat adalah dengan menjadikan diri Anda sebagai teman mereka dan menjadi pendengar yang setia saat mereka bercerita sehingga mereka dapat berkomunikasi dengan nyaman dan tanpa hambatan. $^{28}$

Ketujuh, Orang tua menjadi guru bagi anak-anaknya. Talisaro mengatakan bahwa kebanyakan orang memahami betul bahwa sekolah pertama bagi anak-anak adalah rumah, bukan sekolah. Anak-anak belajar segalanya, baik atau buruk. Pertama-tama, Anda akan menerimanya dalam suasana keluarga. Orang tua dan keluarga memiliki tugas dan kewajiban untuk memberikan contoh dan mengajarkan kepada anak-anaknya nilai pendidikan bahwa membesarkan anak bukanlah tugas yang mudah. Dalam mendidik anak-anaknya, orang tua harus memberikan pengetahuan agama sebagai pedoman bagi anak-anaknya untuk menavigasi kehidupan mereka sendiri di masa depan. ${ }^{29}$ Bila orangtua memberikan perhatian yang baik kepada pendidikan Agama Kristen untuk anak-anaknya, penulis yakin guru agama akan tertolong lebih mudah mendorong anak didik memiliki karakter yang beriman. Selanjutnya Talizaro mengatakan "orang tua harus dapat memberikan contoh dan kebiasaan sehari-hari untuk ditiru oleh anaknya. Alangkah baiknya untuk memberikan beberapa contoh dan kebiasaan yang baik, para orang tua. Karena hal ini dapat mempengaruhi perkembangan jiwa anak." ${ }^{30}$ Firman Tuhan juga menuliskan di dalam 2 Timotius 1:5, "Sebab aku teringat akan imanmu yang tulus ikhlas, yaitu iman yang pertama-tama hidup di dalam nenekmu Lois dan di dalam ibumu Eunike dan yang aku yakini hidup juga di dalam dirimu." Hal ini memberikan sebuah harapan besar bahwa karakter beriman orangtua akan diteladani oleh anak-anak mereka.

\section{Guru Agama Sebagai Konselor Bagi Anak Didik}

Bimbingan konseling yang disediakan di sekolah memegang peranan penting dalam membimbing siswa melalui proses pembelajaran. Layanan harus menggabungkan kegiatan akademik dan pembangunan karakter dengan pendekatan budaya dan spiritual yang baik. Pada hakikatnya setiap kombinasi kegiatan akademik adalah kegiatan pendidikan. ${ }^{31}$ Selain guru agama dan orangtua, maka guru bidang study lainnya juga

\footnotetext{
${ }^{26}$ Ibid.

27 Ibid.

28 Ibid.

${ }^{29}$ Ibid.

30 Ibid.

${ }^{31}$ S. Hutagalung, "Tiga Dimensi Dasar Relasi Manusia Dalam Kehidupan Sosial," Jurnal Koinonia 10, no. 2 (2015). 81-91.
} 
sangat diharapkan untuk membantu pembentukan karakter anak didik, seperti yang dituliskan oleh Stimson Hutagalung terdapat berbagai solusi yang bisa diberikan supaya proses pembimbingan bisa berlangsung dengan optimal. Pertama, Pecah proses kepemimpinan menjadi peta pencapaian yang membahas tiga poin: bagaimana peserta didik dapat mencapai prestasi yang lebih baik dan mengembangkan bakat mereka. bimbingan karir; Dengan kata lain, itu membimbing siswa untuk mencapai tujuan mereka di masa depan. memperbaiki masalah; Ini berarti membimbing siswa dengan masalah dan menyarankan solusi. Kedua, pendidikan karakter dilakukan untuk setiap mata pelajaran dan setiap guru. Misalnya, seorang guru matematika yang menjelaskan materi harus memaksa mereka untuk menghubungkan materi itu dengan pendidikan karakter. Ketiga, pendidikan karakter dikonseptualisasikan dan diintegrasikan ke dalam kurikulum yang diajarkan pada setiap mata pelajaran sebagai bagian dari proses pembelajaran. Buku teks yang berkaitan dengan norma atau nilai setiap mata pelajaran harus dikembangkan dan diteliti serta dihubungkan dengan konteks kehidupan seharihari. ${ }^{32}$ Selanjutnya Stimson juga mengatakan bimbingan dan konseling biasanya berkaitan dengan aspek psikologis. Keterampilan kepemimpinan sangat penting bagi siswa yang mengalami keterbelakangan mental, yang bermasalah, dan yang tidak mengikuti pelajaran dengan baik di kelas. Penyuluhan juga mutlak diperlukan untuk membangkitkan semangat belajar dan membentuk persepsi orang cerdas yang tidak terombang-ambing oleh kebobrokan moral saat ini. Pembentukan akhlak sangat penting dilakukan sejak dini agar kelak anak memiliki sikap dan perilaku yang baik dan tidak menyimpang dari norma yang diterima masyarakat. Moral anak dapat dibentuk melalui harga diri anak. ${ }^{33}$ Esther mengatakan bahwa "penting bagi guru, dalam hal ini guru Pendidikan Agama Kristen, untuk memberikan dukungan dan nasihat untuk membantu siswa mengatasi masalah seperti masalah akademik/akademik, sosial dan pribadi. Mahasiswa yang mendapatkan layanan pendampingan dan konseling dapat membantu mencapai tujuan perkembangannya." 34

\section{Guru agama PAK sebagai guru mata Pelajaran}

Bilamana guru agama PAK bersedia menjadi konselor bagi anak didiknya, itu akan membantu perkembangan karakter mereka. Elisabeth Sitepu mengatakan bahwa Bimbingan konseling di dalam Pendidikan Agama Kristen yang dilakukan oleh Guru Agama untuk dapat mengarahkan, membimbing, membangun hubungan dengan memberikan ayat firman Tuhan dan mendoakan agar siswa memiliki keinginan untuk semangat belajar. ${ }^{35}$ Dengan konseling banyak hal yang akan diketahui dalam kehidupan anak didik dan guru akan semakin tahu cara terbaik untuk mengarahkan anak didik tersebut. Esther mengatakan bahwa "Penelitian menunjukkan bahwa guru PAK yang menengahi masalah siswa menyusun catatan tentang diri mereka sendiri saat menjabat sebagai pengawas. Catatan ini menjadi dokumen penting di sekolah sebagai bahan review siswa bagi guru PAK untuk memahami siswa dengan catatan ini. Dokumen sekolah ini membantu guru memahami potensi siswa dan lingkungannya. Instruktur

\footnotetext{
${ }^{32}$ Hutagalung and Ferinia, "Pengaruh Dekadensi Moral Terhadap Pendidikan Karakter Dan Bimbingan Konseling Pada Siswa Kristen."

33 Ibid.

${ }^{34}$ Esther Rela Intarti and M Th, "Peran Guru Pendidikan Agama Kristen Sebagai Motivator," REGULA FIDEI: Jurnal Pendidikan Agama Kristen 1, no. 2 (2016): 28-40.

${ }^{35}$ Elisabet Sitepu, Thomas P Tarigan, and Desy N Simatupang, " $(38,18<113,14)$ Dan Data Normalitas Hasil Belajar PAK Berdistribusi Normal Dengan Hasil Perhitungan Diperoleh X” 1 (2019): 23-27.
} 
PAK juga dapat mengidentifikasi siswa dengan potensi menyanyi untuk berpartisipasi dalam paduan suara dan tari. Guru PAK juga memahami siswa dalam hal mengajarkan norma-norma agama, seperti yang terlihat dalam buku Pekan Siswa Partisipasi Siswa dalam Ibadah Gereja Anak." ${ }^{6}$

\section{Hal-hal yang harus dipertahankan sebagai guru PAK}

Mengembangkan karakter beriman bagi anak didik adalah salah satu tugas dan tanggungjawab semua guru,khususnya guru agama PAK di sekolah, untuk itu perlu ada yang terus dipertahankan dalam cara mengembangkan karakter tersebut, yaitu:

a. Kasih kepada anak didiknya, Talizaro mengatakan bahwa Cinta mencakup pengabdian, kepedulian, perlindungan, kepedulian, tanggung jawab, kesetiaan. ${ }^{37} \mathrm{Di}$ dalam I Korintus 13 : 4-7 mengatakan indahnya kasih itu dan bahwa kasih itu sangatlah dibutuhkan oleh semua orang, dan kasih itu bahkan tidak akan pernah hilang, bahkan perbuatan kasih menunjukkan bahwa kita adalah warga kerajaan Surga.

b. Harus ada keseimbangan antara disiplin, hukuman dan pujian yang diungkapkan kepada siswa, Talizaro mengatakan bahwa Disiplin sendiri merupakan kebutuhan dasar bagi anak untuk membentuk karakternya. Disiplin bukan hanya tentang hukuman. Disiplin sebenarnya berarti memperhatikan, menjelaskan, dan mengajarkan suatu kebajikan. Disiplin memungkinkan anak-anak untuk mengenali, memilih, dan melaksanakan pilihan mereka dalam kebajikan ini. Disiplin pengasuhan bagi anak juga berkaitan dengan pembentukan kepercayaan pada anak melalui pendidikan, percakapan, dan komunikasi formal dan informal. ${ }^{38}$

c. Keteladanan guru di depan siswa, meliputi perkataan, sikap, penampilan dan perilaku. Di sisi lain, jika guru tidak memberi contoh, itu akan merugikan Anda. Seperti yang ditulis Talizaro, jika seorang anak menerima contoh sikap dan perilaku buruk, saya pikir itu "benar" untuk diikuti. ${ }^{39}$ Itulah sebabnya penting sekali karakter seorang guru agama PAK menjadi teladan bagi anak didiknya.

\section{KESIMPULAN}

Berdasarkan pembahasan di atas, maka kesimpulan dalam penelitian yang berjudul Pendidikan Agama Kristen sebagai strategi dalam menumbuhkan iman anak didik melalui peran guru yang paripurna di masa Pandemi COVID 19 antara lain:

Pertama, Guru Sebagai guru, guru harus memiliki standar kualifikasi pribadi yang meliputi tanggung jawab, wewenang, kemandirian, dan disiplin. Guru PAK adalah pembimbing dan pembimbing yang dengan ilmu dan pengalamannya mampu memimpin dan bertanggung jawab di jalan dan pengembangan karakter Yesus Kristus.

Kedua, Guru agama PAK yang memahami Ilmu Teknologi. Selama pandemi COVID-19, masyarakat harus berkomunikasi dengan media online atau internet. Kemampuan untuk mengikuti kemajuan ilmu pengetahuan dan teknologi sangat penting bagi Guru PAK Agama untuk memastikan siswanya merasa senang dengan pelajarannya.

\footnotetext{
${ }^{36}$ Intarti and Th, "Peran Guru Pendidikan Agama Kristen Sebagai Motivator."

37 Tafonao, "Peran Pengajaran Pendidikan Agama Kristen Dalam Keluarga Sangat Penting Untuk Diajarkan Kepada Anak-Anak, Baik Dalam Keluarga, Sekolah, Di Tempat Ibadah Dan Masyarakat, Agar Kelak Anak-Anak Dapat Menghadapi Setiap Problem Secara Kognitif, Afektif Dan Psik."

38 Ibid.

39 Ibid.
} 
Ketiga, Guru Agama dan Orangtua Anak didik. Sebagai guru yang peduli kepada anak didiknya, guru agama akan membuka komunikasi juga dengan orangtua anak didiknya, agar guru agama mengetahui keadaan mereka dan akan mempermudah komunikasi dan pendidikan kepada anak didiknya

Pelajaran agama di sekolah haruslah menarik minat anak didik, sehingga mereka merasakan suasana rohani yang mampu menumbuhkan iman mereka, dan juga kerinduan mereka untuk menerima kehidupan kekal di Surga. Apabila seorang anak sudah memiliki pengharapan menerima kehidupan kekal di Surga, maka di dunia dia akan menunjukkan sikap seorang yang akan menjadi warga kerajaan Surga. Semoga guru agama PAK di Yayasan SMA Bina Guna mampu menerapkan tulisan ini, sehingga terbentuklah generasi bangsa dan negara yang beriman.

\section{DAFTAR PUSTAKA}

Diane, Priscillia, Joy Joseph, and Fredik Melkias Boiliu. "EDUKATIF : JURNAL ILMU PENDIDIKAN Peran Pendidikan Agama Kristen Dalam Penggunaan Teknologi Pada Anak" 3, no. 4 (2021): 2037-2045.

Hutagalung, S. "Tiga Dimensi Dasar Relasi Manusia Dalam Kehidupan Sosial.” Jurnal Koinonia 10, no. 2 (2015): 81-91.

Hutagalung, Stimson, and Rolyana Ferinia. "Pengaruh Dekadensi Moral Terhadap Pendidikan Karakter Dan Bimbingan Konseling Pada Siswa Kristen." Kurios 7, no. 1 (2021): 178.

Intarti, Esther Rela, and M Th. "Peran Guru Pendidikan Agama Kristen Sebagai Motivator." REGULA FIDEI: Jurnal Pendidikan Agama Kristen 1, no. 2 (2016): $28-40$.

Karnawati, Karnawati, and Mardiharto Mardiharto. "Sekolah Minggu Masa Pandemi Covid 19: Kendala, Solusi, Proyeksi." Didache: Journal of Christian Education 1, no. 1 (2020): 13.

Kementerian Agama Republik Indonesia. "Ketentuan Kegiatan Di Rumah Ibadah Pada PPKM 10 - 16 Agustus 2021.” Kemenag RI. Last modified 2021. https://kemenag.go.id/read/ketentuan-kegiatan-di-rumah-ibadah-pada-ppkm-10-16agustus-2021-gmn9k.

Kreider, Eugene. "Faith Development in Educational Ministry with Children." World XV, no. 1 (1995).

Lane, Tony P. "7 Essentials for Growing Kids' Faith.” Childrensministry. Last modified 2021. https://childrensministry.com/faith-to-grow-on/.

Mambo, Alice W. "Understanding Developmental Characteristics of a Child in Christian Faith among Sunday-School Children in Kenya." IRA International Journal of Education and Multidisciplinary Studies 14, no. 3 (2019): 54.

Van Niekerk, Marsulize, and Gert Breed. "The Role of Parents in the Development of 
Faith from Birth to Seven Years of Age." HTS Teologiese Studies / Theological Studies 74, no. 2 (2018): 1-11.

Paris, Jennifer, Antoinette Ricardo, and Dawn Rymond. Child Growth and Development. The American Catholic Sociological Review. Vol. 11. California: California Community Colleges, Chancellor's Office., 2019.

Sandy, Dimas, Himawan Sogen, Antonius Denny Firmanto, and Ninik Wijayati Aluwesia. "Perkembangan Iman Rasul Cilik Pada Masa Pandemi Covid-19 Paroki Santa Perawan Maria Dari Gunung Karmel Ijen Malang” (n.d.): 11-24.

Setiyowati, Ester Putri, and Yonatan Alex Arifianto. "Hubungan Kompetensi Pedagogik Guru Dan Prestasi Belajar Siswa Pada Mata Pelajaran Pendidikan Agama Kristen.” SIKIP: Jurnal Pendidikan Agama Kristen 1, no. 2 (2020): 78-95.

Sitepu, Elisabet, Thomas P Tarigan, and Desy N Simatupang. “(38,18< 113,14) Dan Data Normalitas Hasil Belajar PAK Berdistribusi Normal Dengan Hasil Perhitungan Diperoleh X" 1 (2019): 23-27.

Sugiyono. "Metode Penelitian Kuantitatif Kualitataif Dan R\&D." 80. Bandung: Alfabeta, 2016.

Tafonao, Talizaro. "Peran Pengajaran Pendidikan Agama Kristen Dalam Keluarga Sangat Penting Untuk Diajarkan Kepada Anak-Anak, Baik Dalam Keluarga, Sekolah, Di Tempat Ibadah Dan Masyarakat, Agar Kelak Anak-Anak Dapat Menghadapi Setiap Problem Secara Kognitif, Afektif Dan Psik." Edudikara: Jurnal Pendidikan dan Pembelajaran 3, no. 2 (2018): 125.

Telaumbanua, Arozatulo. "Peranan Guru Pendidikan Agama Kristen Dalam Membentuk Karakter Siswa." FIDEI: Jurnal Teologi Sistematika dan Praktika 1, no. 2 (2018): 219-231.

Tjandra, Daniel S. "Impelementasi Pembelajaran Pendidikan Agama Kristen Di Abad 21." SIKIP: Jurnal Pendidikan Agama Kristen 1, no. 1 (2020): 1-10. 